REVIEW ARTICLE

\title{
The heat shock protein response and its role in inflammatory disease
}

\author{
Vivienne R Winrow, Lachy McLean, Christopher J Morris, David R Blake
}

The heat shock protein response was first observed in the larvae of the fruit fly Drosophila busckii. ${ }^{1}$ Under conditions of raised temperature, 'puffs' were seen in salivary gland chromosomes, general protein synthesis was switched off, and a set of specific mRNAs was translated to produce the heat shock proteins (HSPs). The significance of these early observations was soon appreciated by molecular biologists, who used them to study the regulation and mechanisms of gene transcription. Only recently have the biological roles of HSPs been investigated. A number of excellent reviews are available ${ }^{2-4}$; this treatise aims at summarising our knowledge of the characterisation, cellular distribution, and function of HSPs, and their possible role in inflammation with specific reference to rheumatology.

\section{Characterisation of heat shock proteins}

It is now well established that HSPs occur in all living organisms and are produced after not only heat shock but also other forms of physiological stress. ${ }^{2}$ We may consider this intracellular response complementary and comparable to the slower developing extracellular acute phase response. It has been shown that the genes coding the proteins produced as a result of hyperthermia contain a specific DNA sequence, the 'heat shock consensus element', 5 which is absent in the genes of proteins produced after some other stress events such as the glucose regulated proteins (GRPs) produced following glucose deprivation; this conserved sequence is located about 20 nucleotides 'upstream' of the 'TATA box' (a common promoter sequence, rich in thymidine and adenine nucleotides, which is found close to the initiation site of eukaryotic genes; an analogous 'box' is found in prokaryotes). As GRPs and HSPs are often produced simultaneously, collectively the proteins are better termed stress proteins. Nevertheless and importantly, the full complement of stress proteins is not induced by every stressor. For example, the human stress protein with a molecular weight of 32000 daltons $(32 \mathrm{kD})$ can be induced by heavy metals and thiolreactive agents but not by hyperthermia, the calcium ionophore A23187, or amino acid analogues. ${ }^{6}$ This protein does not contain a heat shock consensus element, but we believe it to be important in rheumatology as many of our disease suppressing therapeutic compoundsfor example, gold, D-penicillamine-either contain or affect the inducers of this protein. ${ }^{7}$
Stress proteins are divided into subsets or 'families' according to their molecular weight, which is a source of confusion. Although the genes are remarkably well conserved between species, the proteins vary slightly in molecular weight; thus the $32 \mathrm{kD}$ human stress protein becomes the $34 \mathrm{kD}$ murine protein. The best studied family of proteins is the $70 \mathrm{kD}$ family. In man this family is now known to consist of five structurally and immunologically related proteins (table 1). The proteins are characterised in terms of their molecular weight and isoelectric point (pI) as the method most commonly used to visualise these proteins is that of two dimensional electrophoresis. Firstly, the proteins are separated on a $\mathrm{pH}$ gradient gel (isoelectric focusing) and then in the second dimension by molecular weight (sodium dodecyl sulphate-polyacrylamide gel electrophoresis). The $\mathrm{pH}$ gradient separates differentially phosphorylated isomers of stress proteins-for example, there are three isomers of the $28 \mathrm{kD}$ protein, which are not all expressed simultaneously in a given cell. The $70 \mathrm{kD}$ family is complicated, however, and there seem to be differences between cell types. Further confusion arises owing to slight variations in gel systems, leading to different workers using different names for the stress proteins. Thus Welch names the most abundant $70 \mathrm{kD}$ proteins as 72 $\mathrm{kD}$ and $73 \mathrm{kD}$ while Morimoto uses $70 \mathrm{kD}$ and $72 \mathrm{kD}$ respectively. ${ }^{8}$ Nevertheless, the proteins are biochemically equivalent, the $72 / 70 \mathrm{kD}$ protein being indicative of and specific to a stress response; the $73 \mathrm{kD}$ ( $\mathrm{pI} 5.5$ ) protein is produced constitutively. Their drosophila counterparts have molecular weights of $68 \mathrm{kD}$ and $70 \mathrm{kD}$. In table 1 alternative names ${ }^{89}$ are given, though direct comparison is often impossible. In this review the Welch nomenclature for the $70 \mathrm{kD}$ family will be used.

Another major family of stress proteins is the $90 \mathrm{kD}$ family, and there are low molecular weight stress proteins which have been cate-

Table 1: Human 70 kD family

\begin{tabular}{llll}
\hline Protein & $\begin{array}{l}M o l w t \\
(k D)^{*}\end{array}$ & $p I^{*}$ & Other names \\
\hline Constitutive & 73 & $5 \cdot 5$ & $72, \dagger$ HSC70 \\
Stress inducible & 72 & $5 \cdot 6$ & $70 \dagger$ \\
Stress inducible & 73 & $6 \cdot 3$ & HSX70/HSP70 \\
Constitutive & $74-78$ & & GRP78/80 kD \\
Mitochondrial & 75 & &
\end{tabular}

*After Minota et al. ${ }^{53}$

†After Milarski et al. ${ }^{8}$ †After Pelham. 
Table 2: Human families

\begin{tabular}{l} 
Mol wt $(k D)$ \\
\hline $90-100,90$ \\
$70-$ See table 1 \\
$65-58 \cdot 6$ \\
$20-28,32$ \\
-Low molecular weight proteins \\
Ubiquitin \\
\hline
\end{tabular}

gorised as a $20 \mathrm{kD}$ family. Table 2 gives the constituent members of the human families. The $65 \mathrm{kD}$ family is very important in bacterial systems; the mycobacterial $65 \mathrm{kD}$ protein seems to be involved in the development of adjuvant arthritis and will be discussed in a later section. Ubiquitin, a 76 amino acid protein, is also an HSP and has been implicated in certain neurological diseases. ${ }^{10}$

Because of the high degree of homology between species ${ }^{11}$ and because the proteins are highly antigenic, antibodies raised against HSPs of one species often cross react with another. This is not absolute, however, as a monoclonal antibody (TB78) which recognises the $65 \mathrm{kD}$ protein of Mycobacterium tuberculosis does not cross react with the Escherichia coli GroEL protein or the human $65 \mathrm{kD}$ mitochondrial protein, whereas ML30, raised against Mycobacterium leprae, is broadly cross reactive ( $\mathrm{J}$ Ivanyi, personal communication). GroEL is the 'common antigen' detected in about 50 species of bacteria and shows considerable homology to the $65 \mathrm{kD}$ mycobacterial protein. ${ }^{12}$ Table 3 lists some bacterial and human homologous proteins.

\section{Function and cellular localisation of stress proteins}

Until recently, the functions of HSPs remained a matter of speculation, ${ }^{9}$ clear evidence being available for the $70 \mathrm{kD}$ family only. Transfection of cells with a plasmid which overproduces HSP70 accelerates their recovery from heat shock, ${ }^{13}$ and more recently it was shown that the microinjection of monoclonal antibodies to HSP70 before heat shock was lethal to fibroblasts. ${ }^{14}$ Thus these proteins are clearly necessary in helping cells survive physiological stress. The effect is fully reversible, total protein synthesis recovering within a few hours of the return to normal temperatures. ${ }^{2}{ }^{15}$ In addition, cells can be rendered 'tolerant' by repeated stress events and subsequently require more severe conditions to reinitiate HSP synthesis. ${ }^{2} 416$

The $70 \mathrm{kD}$ proteins show the highest degree of interspecies.homology at the $\mathrm{NH}_{2}$ terminus of the protein, and it has been shown that this region has an ATPase activity. This activity is responsible for the disruption of the clathrin

Table 3: Homologous interspecies stress proteins Molecular weights $(k D)$

\begin{tabular}{llll}
\hline$M$ leprae & $M$ tuberculosis & E coli & Human \\
\hline 65 & 65 & GroEL & $58 \cdot 6$ \\
70 & 71 & dnaK & See table 1 \\
\hline
\end{tabular}

cages covering coated vesicles, which are intermediates in the pathway of receptor mediated endocytosis. ${ }^{17}$ In the human this activity is ascribed to the $72 / 73 \mathrm{kD}$ proteins. ${ }^{3}$ The $70 \mathrm{kD}$ proteins are localised in the cytoplasm and nucleus but after heat shock are concentrated in the nucleus and nucleoli, where they bind to partially assembled ribosomes; the human 72 $\mathrm{kD}$ protein co-localises with ribosomes. ${ }^{18}$ Heat shock and other stressors cause a rapid collapse of the intermediate filaments, particularly vimentin, in and around the nucleus and the mitochondria, and ribosomes become trapped within this network. Again, it is the human 73 $\mathrm{kD}$ and $72 \mathrm{kD}$ proteins which are found associated with microtubules and vimentin. ${ }^{319} 20$ The GRP78 member of this family (unaffected by heat) is always found in the lumen of the endoplasmic reticulum.

The HSP70 family of proteins has been referred to as ATP dependent 'unfoldases', 'molecular chaperones', or 'chaperonins'. This implies that they function in recognising nascent proteins and incorrectly folded or glycosylated proteins, and correct problems incurred during their association into oligomeric structures. Indeed it has recently been shown that a protein which binds to immunoglobulin heavy chain (BiP-immunoglobulin binding protein) is homologous to GRP78, ${ }^{21}$ and also that in yeast, a eukaryote, HSP70 aids in the translocation of precursor protein into microsomes, ${ }^{22}$ mitochondria, and the lumen of the endoplasmic reticulum ${ }^{23}$ (ATP-dependent unfoldases), and subsequently HSP60 assembles protein subunits within the yeast mitochondria. ${ }^{24}$

A number of workers have implicated HSPs in developmental control and in infection. Heat stress is often used to produce developmental defects in drosophila. ${ }^{25}$ It may be important in the life cycle of certain parasites which use insect vectors, where they pass from the $25^{\circ} \mathrm{C}$ poikilothermic host to $37^{\circ} \mathrm{C}$ in a mammalian host. Thus Trypanosoma cruzi, the aetiological agent in Chagas' disease, expresses HSP70 antigens, ${ }^{26}$ and Plasmodium falciparum, the causative agent of human malaria, bears an HSP70 related protein in its merozoite form in human blood. ${ }^{27}$ Leishmania protozoa and schistosoma worms also express HSP70-like antigens (Young D B, Mehlert A, Smith D F, unpublished data). As has been stated, mycobacteria bear multiple HSP antigens. This has led to the idea that these antigens may be implicated in autoimmune disease by the process of 'molecular mimicry'. ${ }^{28} 29$ Interestingly, many of the proteins bound by HSPs (immunoglobulin, vimentin, histones) are common targets of autoantibody formation in rheumatic disease.

The $90 \mathrm{kD}$ HSP is a cytoplasmic protein with many isoelectric forms. It can associate with tyrosine kinases. ${ }^{30}$ and is also a constituent of the steroid hormone receptor complex. ${ }^{30}{ }^{31}$ The $100 \mathrm{kD}$ stress protein is glucose regulated and is present in the Golgi. High molecular weight stress proteins occur; little is known of the nucleolar $110 \mathrm{kD}$ protein. ${ }^{32}$ There is no $100 \mathrm{kD}$ or $110 \mathrm{kD}$ counterpart in drosophila. ${ }^{2}$

Although there is a vast number of publications about the 7-8 $\mathrm{kD}$ protein, ubiquitin, less 
is known of the functions of other low molecular weight stress proteins. Ubiquitin, the most highly conserved HSP, performs a number of essential cellular functions, attaching to cytosolic proteins and marking them for degradation when beyond salvage by the $70 \mathrm{kD}$ family. Also, it attaches to certain histones in chromatin, ${ }^{33}$ and a role in HSP transcription has been suggested. $^{25} 34$ The mammalian (rat) $28 \mathrm{kD}$ protein consists of at least four isoforms, three of which are differentially phosphorylated; the degree of phosphorylation of the $28 \mathrm{kD}$ protein, but not the synthesis, is dramatically increased after exposure to mitogens or phorbol estersthat is, cell activation. 35

Recently, it was shown that the major $32 \mathrm{kD}$ stress protein produced by a human skin fibroblast cell line after ultraviolet irradiation or exposure to hydrogen peroxide is the enzyme haem oxygenase. ${ }^{36}$ This is the protein induced by metals and thiol reactive agents. Speculations on its role in disease are given below.

\section{Stress proteins in inflammatory rheumatic disease}

What is the relevance of these proteins to rheumatology? Perhaps the most direct answer is simply that we do not know. Two independent pieces of evidence attach unequivocal importance to HSPs in rheumatic disease, however. The first is the observation of Lakomek et al, who, while screening patients' sera for antinuclear antibodies, exploiting the large polytene chromosomes from the salivary glands of heat shocked drosophila larvae, showed that $39 \%$ of patients with ankylosing spondylitis produce antibodies reactive only with a certain (93 D) heat shock puff; serum samples from patients with other forms of rheumatic disease or from healthy controls showed no reactivity at this chromosome locus. ${ }^{37}$ More recently, Brand et al have shown that $49 \%$ of patients with ankylosing spondylitis have antibodies against the $63 \mathrm{kD}$ HSP - again with exquisite disease specificity. ${ }^{38}$ The association between ankylosing spondylitis and the major histocompatibility antigen HLAB27 is well reported ${ }^{39}$; associations of ankylosing spondylitis or B27 with klebsiella and other Gram negative organisms have been the subject of much controversy. ${ }^{40-43}$ It can be no accident that the organisms triggering B27 associated reactive arthritis are all intracellular parasites, and can be expected to express ample $65 \mathrm{kD}$ HSP when inside host phagocytes. Stress proteins may prove to be the 'missing link'.

The second direct link is through the rat model of adjuvant induced arthritis. Arthritis is induced by injection of Freund's adjuvant, a suspension of heat killed $M$ tuberculosis in oil, the arthritis appearing 11-13 days later. It was shown that transfer of an autoreactive $T$ cell clone recognising a determinant on the mycobacterial $65 \mathrm{kD}$ antigen to a heavily irradiated syngeneic rat was arthritogenic; prior immunisation with the purified $65 \mathrm{kD}$ antigen abrogated this effect. ${ }^{44}$ Interestingly, these clones also recognise the core protein of cartilage proteoglycan, implying some degree of joint specificity. ${ }^{45}$ In addition, peripheral blood and synovial fluid lymphocytes of patients with rheumatoid arthritis showed this cross reactivity, the $T$ cells recognising both the $65 \mathrm{kD}$ antigen and cartilage proteoglycan. ${ }^{46}$ In reactive arthritis, known to be induced by an infectious agent, synovial fluid $T$ cells reactive with salmonella antigens demonstrated reactivity with a recombinant 65 $\mathrm{kD}$ protein of $M$ leprae; this cross reactivity was not seen with peripheral blood $\mathrm{T}$ cells, again suggesting joint specificity. ${ }^{47}$

Further supporting evidence for the role of HSPs in rheumatology is circumstantial. This includes the observation that chondrocytes from patients with osteoarthritis constitutively produce $70 \mathrm{kD}$ and $90 \mathrm{kD}$ proteins,${ }^{48}$ and sera from patients with rheumatoid arthritis recognise $70 \mathrm{kD}$ and $28 \mathrm{kD}$ antigens in extracts of synoviocytes. $^{49}$ Our own immunohistological studies have shown the presence of the highly inducible (stress specific) human $72 \mathrm{kD}$ protein in synovium from patients with rheumatoid arthritis and osteoarthritis, ${ }^{50}$ while others have detected raised serum IgG and IgA antibodies to human $70 \mathrm{kD}$ and mycobacterial $65 \mathrm{kD}$ HSPs; the levels were not related to age, sex, duration or activity of disease and were not associated with any particular HLA-DR haplotype. ${ }^{51}$ Patients with systemic lupus erythematosus have serum IgG antibodies to HSP90 ${ }^{52}$ and both IgM and IgG antibodies to a constitutively produced member of the $70 \mathrm{kD}$ family $(73$

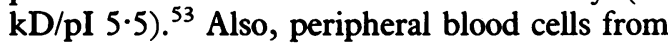
patients with systemic lupus erythematosus produce raised levels of HSPs. ${ }^{54}$ In a recent communication raised IgG (but not IgM) antibodies to the Golgi complex were reported in the sera of patients with primary Sjögren's syndrome $\mathrm{e}^{55}$; this is the site of the $100 \mathrm{kD}$ stress protein.

Speculations on the role of stress proteins in synovitis

As heat is one of the five cardinal signs of inflammation and as HSPs can be induced by a number of stressors, including hypoxia, reactive oxygen species, and cytokines, it is perhaps not surprising that such proteins are found at sites of inflammation. Although the benefit of heat treatment in arthritis remains controversial, recent evidence suggests that selective application of deep heat to the synovium ('thermal synovectomy') is therapeutic. ${ }^{56}$ Such targeting, leading to localised HSP production, may be important as similar cells from different $\operatorname{sites}^{57}$ and different cells from adjacent tissues ${ }^{58}$ appear to show differential expression of HSPs. Whether these differences are related to maturation or site and whether changes occur in disease states remains to be elucidated. Repeated heat shock can induce a state of thermotolerance to cells in vitro and this tolerance also aids the cell in overcoming further stressors. ${ }^{16}$ It is tempting to speculate that this is one of the mechanisms which downregulates acute episodic 'flares' in palindromic and early rheumatoid arthritis. Clearly many questions remain unanswered!

We have postulated that reactive oxygen metabolites, including hydrogen peroxide 
$\left(\mathrm{H}_{2} \mathrm{O}_{2}\right)$, superoxide $\left(\mathrm{O}_{2}^{-\bullet}\right)$, and the hydroxyl radical $\left({ }^{\bullet} \mathrm{OH}\right)$, are released, probably from endothelial cells, as a consequence of hypoxic reperfusion injury in a mobile inflamed joint. ${ }^{59}$ Polla has suggested that stress proteins may have antioxidant effects as they show increased synthesis in the presence of reactive oxygen metabolites ${ }^{60}$; Burdon (personal communication) has found that hydrogen peroxide (possibly -OH radical) but not superoxide induces HSP synthesis. The recent work by Keyse and Tyrrell defines the major $32 \mathrm{kD}$ stress protein induced by $\mathrm{H}_{2} \mathrm{O}_{2}$ as the enzyme haem oxygenase. ${ }^{36}$ This enzyme cleaves haem to form biliverdin, which is subsequently converted to bilirubin. Bilirubin, whether unconjugated or albumin bound, is an efficient free radical scavenger.

Normal movement of an inflamed joint generates pressure such that transient synovial capillary ischaemia inevitably follows. Transient anaerobic exposure leads to the induction of GRPs. ${ }^{61}$ As the pressure falls, reperfusion occurs, leading to the release of oxidants which have the capacity to denature proteins. ${ }^{62-64}$ The damage to the intermediate filament protein, vimentin, is of particular interest as collapse of the cytoskeleton is a prerequirement of HSP release. Our previous work showed that synovial cells have abnormal intermediate filaments ${ }^{65}$ and also that these are very susceptible to damage induced by reactive oxygen species. ${ }^{63}$ Recently, there have been a number of reports of reduced glycosylation of IgG in rheumatoid arthritis and it is known that glycosylation of cellular proteins is inhibited during heat shock while hypoglycosylated proteins accumulate intracellularly ${ }^{66}$ Release of cytoplasmic contents to the local environment is an inevitable consequence of cell destruction in inflamed tissue and thus immunological reactivity against these intracellular proteins may arise. Alternatively, the propensity of certain HSPs to bind IgG and related proteins destined for export raises the possibility that some HSPs may indeed reach the cell membrane in immunogenic form. Both reactive oxygen species and abnormal proteins serve as stress signals and trigger the activation of heat shock genes. ${ }^{67}$ In particular, $\mathrm{H}_{2} \mathrm{O}_{2}$ specifically induces the synthesis of haem oxygenase, which theoretically would abrogate further protein damage by haem iron catalysed - $\mathrm{OH}$ radical formation. Thus there exists in the joint a highly regulated but complex defence system for limiting hypoxic-reperfusion injury. Interestingly, it has been shown that penicillamine acts in suppressing endothelial cell proliferation by generating low levels of $\mathrm{H}_{2} \mathrm{O}_{2}{ }^{68}$

\section{Concluding remarks}

Heat shock proteins are both highly conserved and immunogenic. The latter property has suggested to some a role in the maintenance of synovitis by an autoimmune reaction. Conversely, their induction may limit the inflammatory response, protecting the cell in various ways from a variety of insults. Are stress proteins friend or foe to the rheumatic patient? The answer, like so many answers to such fundamental questions in rheumatology, appears to be yes!

The authors wish to thank Dr W J Welch for reading the manuscript.

1 Ritossa F. A new puffing pattern induced by temperature shock and DNP in Drosophila. Experientia 1962; 18: 571-3. 2 Lindquist S. The heat-shock response. Annual Review of Biochemistry 1986; 55: 1151-91.

3 Welch W J. The mammalian heat shock (or stress) response: a cellular defense mechanism. Adv Exp Med Biol 1987; 225: 287-304.

4 Subjeck J R, Shyy T T. Stress protein systems of mammalian cells. Am $\mathcal{F}$ Physiol 1986; 250: C1-17.

5 Pelham $H$ R B. A regulatory upstream promoter element in the Drosophila HSP70 heat-shock gene. Cell 1982; 30: 517-28.

6 Caltabiano M M, Koestler T P, Poste G, Greig R G. Induction of $32-$ and $34-\mathrm{kDa}$ stress proteins by sodium arsenite, heavy metals, and thiol-reactive agents. $\mathcal{F}$ Biol Chem 1986; 261: 13381-6.

7 Caltabiano M M, Poste G, Greig R G. Induction of the 32-kD human stress protein by auranofin and related triethylphosphine gold analogs. Biochem Pharmacol 1988; 37: 4089-93.

8 Milarski K L, Welch W J, Morimoto R I. Cell cycledependent association of HSP70 with specific cellular proteins. F Cell Biol 1989; 108: 413-23.

9 Pelham H R B. Speculations on the functions of the major heat shock and glucose-regulated proteins. Cell 1986; 46: 959-61.

10 Lowe J, Blanchard A, Morrell $\mathrm{K}$, et al. Ubiquitin is a common factor in intermediate filament inclusion bodies of diverse type in man, including those of Parkinson's disease, diverse type in man, including those of Parkinson's disease,
Pick's disease, and Alzheimer's disease, as well as Rosenthal fibres in cerebellar astrocytomas, cytoplasmic bodies in muscle, and Mallory bodies in alcoholic liver disease. $\mathcal{f}$ Pathol 1988; 155: 9-15.

11 Young D B, Ivanyi J, Cox J H, Lamb J R. The $65 \mathrm{kDa}$ antigen of mycobacteria-A common bacterial protein? Immunology Today 1987; 8: 215-9.

12 Thole J E R, Hindersson P, de Bruyn J, et al. Antigenic relatedness of a strongly immunogenic $65 \mathrm{kDa}$ mycobacterial protein antigen with a similarly sized ubiquitous bacterial common antigen. Microbial Pathogenesis 1988; 4: bacterial

13 Pelham H R B. HSP70 accelerates the recovery of nucleolar morphology after heat shock. EMBO $71984 ; 3: 3095-100$.

14 Riabowol K T, Mizzen L A, Welch W J. Heat shock is lethal to fibroblasts microinjected with antibodies against hsp70. Science 1988; 242: 433-6.

15 Yost H J, Lindquist S. RNA splicing is interrupted by heat shock and is rescued by heat shock protein synthesis. Cell 1986; 46: 185-93.

16 Carper S W, Duffy J J, Gerner E W. Heat shock proteins in thermotolerance and other cellular processes. Cancer Res 1987; 47: 5249-55.

17 Chappell T G, Welch W J, Schlossman D M, Palter K B, Schlesinger $M J$, Rothman J E. Uncoating ATPase is a member of the 70 kilodalton family of stress proteins. Cell 1986; 45: 3-13.

18 Welch W J, Suhan J P. Cellular and biochemical events in mammalian cells during and after recovery from physiological stress. F Cell Biol 1986; 103: 2035-52.

19 Biessman H, Falkner F-G, Saumweber H, Walter M F. Disruption of the vimentin cytoskeleton may play a role in heat-shock responses. In: Schlesinger $M J$, Ashburner $M$, Tissières A, eds. Heat shock: from bacteria to man. New York: Cold Spring Harbor Laboratory, 1982: 275-81.

20 Welch W J, Feramisco J R, Blose S H. The mammalian stress response and the cytoskeleton: alterations in intermediate filaments. Ann NY Acad Sci 1985; 455: 57-67.

21 Munro S, Pelham H R B. An HSP70-like protein in the ER: identity with the $78 \mathrm{kd}$ glucose-regulated protein and immunoglobulin heavy chain binding protein. Cell 1986; 46: 291-300.

22 Chirico W J, Waters M G, Blobel G. 70K heat shock related proteins stimulate protein translocation into microsomes. Nature 1988; 332: 805-10.

23 Deshaies R J, Koch B D, Werner-Washburne M, Craig E A, Schekman R. A subfamily of stress proteins facilitates translocation of secretory and mitochondrial precursor polypeptides. Nature 1988; 332: 800-5

24 Cheng M Y, Hartl F-U, Martin J, et al. Mitochondrial heatshock protein hsp60 is essential for assembly of proteins imported into yeast mitochondria. Nature $1989 ; 337: 620-5$.

25 Munro S, Pelham H R B. What turns on heat shock genes? Nature 1985; 317: 477-8.

26 Requena J M, Lopez M C, Jimenez-Ruiz A, de la Torre J C, Alonso C. A head-to-tail tandem organisation of hsp70 Alonso C. A head-to-tail tandem organisation of hsp70
genes in Trypanosoma cruzi. Nucleic Acids Res 1988; 16: genes in $1393-406$.

27 Bianco A E, Favaloro J M, Burkot T R, et al. A repetitive antigen of Plasmodium falciparum that is homologous to antigen of Plasmodium falciparum that is homologous to heat shock protein 70 of Drosophila melanogaster. Proc Natl
Acad Sci USA 1986; 83: 8713-7. Acad Sci USA 1986; 83: 8713-7.

Oldstone M B A. Molecular mimicry and auto-immune disease. Cell 1987; 50: 819-20.

29 Young D, Lathigra R, Hendrix R, Sweetser D, Young R A. Stress proteins are immune targets in leprosy and tuberculosis. Proc Natl Acad Sci USA 1988; 85: 4267-70. 
30 Schuh S, Yonemoto W, Brugge J, et al. A 90,000-dalton binding protein common to both steroid receptors and the Rous sarcoma virus transforming protein pp60v-src. $\mathcal{f}$ Bio Chem 1985; 260: 14292-6.

31 Catelli M G, Binart N, Jung-Testas, et al. The common 90 $\mathrm{kD}$ protein component of non-transformed ' $8 \mathrm{~S}$ ' steroid receptors is a heat shock protein. EMBOF $1985 ; 4: 3131-5$.

32 Subjeck J R, Shyy T T, Shen J, Johnson R J. Association between the mammalian 110,000 -dalton heat-shock protein and nucleoli. $\mathcal{F}$ Cell Biol 1983; 97: 1389-95.

33 Rechsteiner M, ed. Ubiquitin. New York: Plenum, 1988

34 Burdon R H. The heat shock proteins. Endeavour 1988; 12 133-8.

35 Welch W J. Phorbol ester, calcium ionophore, or serum added to quiescent rat embryo fibroblast cells all result in the elevated phosphorylation of two 28,000 -dalton mammalian stress points. $\mathcal{F}$ Biol Chem 1985; 260: $3058-62$.

36 Keyse S M, Tyrrell R M. Heme oxygenase is the major 32 $\mathrm{KDa}$ stress protein induced in human skin fibroblasts by UVA radiation, hydrogen peroxide, and sodium arsenite. Proc Natl Acad Sci USA 1989; 86: 99-103.

37 Lakomek H-J, Will H, Zech M, Krüskemper H L. A new serologic marker in ankylosing spondylitis. Arthritis Rhem 1984; 27: 961-7.

38 Brand S R, McIntosh D P, Bernstein R M. Antibody to a $63 \mathrm{kD}$ protein in ankylosing spondylitis [Abstract]. $\mathrm{Br} F$ Rheumatol 1989; 28 (suppl 1): 5 .

39 Brewerton D A, Caffrey M, Hart F D, James D C O Brewerton D A, Cafrey M, Hart F D, James D C O,
Nicholls A, Sturrock R D. Ankylosing spondylitis and Nicholls A, Sturrock R D. An

40 Kinsella T D, Fritzler M J, McNeil D J. Ankylosing spondylitis. A disease in search of microbes. $f$ Rheumato $1983 ; 10: 2-4$

41 Ebringer A. The cross-tolerance hypothesis, HLA-B27 and ankylosing spondylitis. $\mathrm{Br} \mathcal{F}$ Rheumatol 1983; 22: (suppl 2) 53-66.

42 Prendergast J K, Sullivan J S, Geczy A F, Upfold L I Edmonds J P, Bashir H V. The enigma of the Klebsiella connection and ankylosing spondylitis: a commentary. Hum Immunol 1984; 9: 131-6.

43 Archer J R, Winrow V R, McLean I L. The role of HLA-B27 in arthritis. $B r \mathcal{F}$ Rheumatol 1988; 27: 306-9.

44 van Eden W, Thole J E R, van der Zee R, et al. Cloning of the mycobacterial epitope recognised by $T$ lymphocytes in adjuvant arthritis. Nature $1988 ; 331: 171-3$.

45 van Eden W, Holoshitz J, Nevo Z, Frenkel A, Klajman A, Cohen I R. Arthritis induced by a T-lymphocyte clone that responds to Mycobacterium tuberculosis and to cartilage

proteoglycans. Proc Natl Acad Sci USA 1985; 82: 5117-20. Holoshitz J, Klajman A, Druker I, et al. T lymphocytes of rheumatoid arthritis patients show augmented reactivity to a fraction of mycobacteria cross-reactive with cartilage. Lance 1986; ii: 305-9.

47 Gaston J S H, Life P F, Bailey L, Bacon P A. Synovial fluid T cells and $65 \mathrm{kD}$ heat-shock protein. Lancet 1988 ; ii: 856 .

48 Kubo T, Towle C A, Mankin H J, Treadwell B V. Stressinduced proteins in chondrocytes from patients with osteoinduced proteins in chondrocytes from patien

49 Pérez-Maceda B, Bernabeu C, López-Bote J P, Marquet A, Larraga V. Autoantibodies from rheumatoid arthritis patients recognize antigens on the synoviocyte surface. Scand F Immunol 1988; 27: 295-304.
50 McLean I L, Winrow V R, Mapp P I, Cherrie A H, Archer J $R$, Blake D R. Synovial fluid T cells and $65 \mathrm{kD}$ heat-shock protein. Lancet 1988; ii: 856-7.

51 Tsoulfa G, Rook G A W, van-Embden J D A, et al. Raised serum IgG and IgA antibodies to mycobacterial antigens in rheumatoid arthritis. Ann Rheum Dis 1989; 48: 118-23.

52 Minota S, Koyasu S, Yahara I, Winfield J. Autoantibodies to the heat-shock protein hsp90 in systemic lupus erythematosus. $\mathcal{F}$ Clin Invest 1988; 81: 106-9.

53 Minota S, Cameron B, Welch W J, Winfield J B. Autoantibodies to the constitutive 73-kD member of the hsp70 family of heat shock proteins in systemic lupus erythematosus. F Exp Med 1988; 168: 1475-80.

54 Deguchi $\mathrm{Y}$, Negoro $S$, Kishimoto $S$. Heat-shock protein synthesis by human peripheral mononuclear cells from SLE pynthesis by human peripheral mononuclear cells from SLE

55 Blaschek M A, Pennec Y L, Simitzis A M, et al. Anti-Golgi complex autoantibodies in patients with primary Sjögren's syndrome. Scand F Rheumatol 1988; 17: 291-6.

56 Weinberger A, Fadilah R, Lev A, Levi A, Pinkhas J. Deep heat in the treatment of inflammatory joint disease. Med Hypotheses 1988; 25: 231-3.

57 Ketis N V, Hoover R L. Effects of hyperthermia on cell survival and patterns of protein synthesis in endothelial cells from different origins. Cancer Res 1988; 48: 2101-6.

58 White F P. Differences in protein synthesized in vivo and in vitro by cells associated with the cerebral vasculature. A protein synthesized in response to trauma? Neuroscience protein synthesized

59 Blake D R, Merry P, Unsworth J, et al. Hypoxic-reperfusion injury in the inflamed human joint. Lancet 1989; i: 289-93.

60 Polla B S. A role for heat shock proteins in inflammation? Immunology Today 1988; 9: 134-7.

61 Sciandra J J, Subjeck J R, Hughes C S. Induction of glucoseregulated proteins after anaerobic exposure and of heat shock proteins after reoxygenation. Proc Natl Acad Sci USA 1984; 81: 4843-7.

62 Lunec J, Blake D R, McCleary S J, Brailsford S, Bacon P A. Self-perpetuating mechanisms of IgG aggregation in theumatoid inflammation. 7 Clin Invest 1985; 76: 2084-90.

63 Marjanovic M, Hewitt S D, Morris C J, Lunec J, Blake D R. Cytoskeletal changes following free-radical attack. $\mathrm{Br} \mathscr{f}$ Rheumatol 1987; 26 (suppl 2): 69.

64 Winyard P G, Hider R C, Brailsford S, Drake A F, Lunec J, Blake D R. Effects of oxidative stress on some physicoBlake D R. Effects of oxidative stress on some physico-
chemical properties of caeruloplasmin. Biochem $\mathcal{F} 1989 ; 258$ : 435-45.

65 Morris C J, Farr M, Hollywell C A, Hawkins C F, Scott D L, Walton $\mathrm{K}$ W. Ultrastructure of the synovial membrane in seronegative inflammatory arthropathies. $\mathcal{F} R$ Soc Med 1983; 76: 27-31.

66 Garry R F, Bostick D A. Induction of the stress response: alterations in membrane-associated transport systems and protein modification in heat shocked or Sindbis virusinfected cells. Virus Res 1987; 8: 245-59.

67 Ananthan J, Goldberg A L, Voellmy R. Abnormal protein serve as eukaryotic stress signals and trigger the activation of heat shock genes. Science 1986; 232: 522-4.

68 Matsubara T, Saura R, Hirohata K, Ziff M. Inhibition of human endothelial cell proliferation in vitro and neovascuhuman endothelial cell proliferation in vitro and neovascularization 